\title{
DYSMENORRHEA MANAGEMENT BY NON-MEDICAL FACULTIES STUDENTS OF UNIVERSITAS MUHAMMADIYAH SURAKARTA IN 2019
}

\section{MARISKA SRI HARLIANTI*, RATIH DWI WIDIASTUTI}

Department of Pharmaceutics , Faculty of Pharmacy, Universitas Muhammadiyah Surakarta 57102, Indonesia. Email: mariska@ums.ac.id Received: 12 March 2020 , Revised and Accepted: 20 April 2020

\author{
ABSTRACT \\ Objective: The aim of this study was to investigate the dysmenorrhea management by non-medical Faculties Students of Universitas Muhammadiyah \\ Surakarta through self-medication.
}

Methods: An observational study with cross-sectional design was conducted across 394 respondents at non-medical Faculties of Universitas Muhammadiyah Surakarta. Respondents were selected by purposive sampling method. Data were obtained using questionnaire that filled out by respondents.

Results: Among the 394 respondents, 100\% managed dysmenorrhea by non-pharmacological treatment $(88.78 \%$, 53.83\%, and 42.35\% were sleeping and taking a rest, eating nutritrious food, and compressing with warm water), whereas 160 (40.82\%) respondents managed dysmenorrhea by taking medicines $(70.62 \%, 16.88 \%, 11.25 \%$ and $1.25 \%$ were unidentified, over the counter, mandatory drug pharmacy [Obat Wajib Apotek], and prescription only medicine).

Conclusion: Dysmenorrhea management among non-medical Faculties Students of Universitas Muhammadiyah frequently appropriate. The role of pharmacists in providing information about medicine used by community was very important because many respondents do not know the names or brands.

Keywords: Dysmenorrhea, Non-medical faculty, Self-medication.

(C) 2021 The Authors. Published by Innovare Academic Sciences Pvt Ltd. This is an open access article under the CC BY license (http://creativecommons. org/ licenses/by/4.0/) DOI: http://dx.doi.org/10.22159/ijap.2021.v13s1.Y0084. Journal homepage: https://innovareacademics.in/journals/index.php/ijap

\section{INTRODUCTION}

Dysmenorrhea is a medical condition in menstrual cycle, characterized by painful menstrual cramps of uterine origin. The prevalence of dysmenorrhea varies 45-95\%, regardless of age and nationality [1]. Adolescents having the highestrate of dysmenorrhea. An estimated $15 \%$ of adolescents female describe their pain as severe [2]. Dysmenorrhea is associated with a restriction of activity and absence from school and work, especially when it is severe [1]. The adolescents miss from school at least 1-3 days per menstrual cycle. Dysmenorrhea causes a decrease in academic performance and quality of sleep so that it results on anxiety and depression [2]. Few women with dysmenorrhea seek treatment (pharmacological and non-pharmacological) because this substantial effect on their quality of life and general well-being [1].

Dysmenorrhea is a minor ailment so that it can be treated by over the counter's (OTC) medicine [3]. The selection and use of medicine by individuals to treat self-recognized illness or symptoms called selfmedication. In 2011, 91\% population of Indonesian practiced selfmedication [4]. The medicine that can use in self-medication cases is limited only OTC medicine and mandatory drug pharmacy (Obat Wajib Apotek) [5].

Dysmenorrhea can be treated in various ways, pharmacological, and non-pharmacological. Pharmacological treatments of dysmenorrhea are nonsteroidal anti-inflammatory drugs (NSAIDs), paracetamol, and anticholinergic antispasmodic [3]. Non-pharmacological treatments of dysmenorrhea are as follows: Herbal therapy, dietary changes, physical exercise, the use of heat patch $\left(39^{\circ} \mathrm{C}\right)[1]$, massage and aromatherapy [6], mineral supplement, smoking cessation, weight management, relaxation technique, and alcohol limits would be useful to reduce severity of symptoms [3]. Appropriate self-medication can relieve the symptoms, save time and money also patient's life in acute conditions. Inappropriate self-medication cause drug-related problems and life threatening [5].

The aim of this study was to investigate the dysmenorrhea management by non-medical faculties students of Universitas Muhammadiyah Surakarta through self-medication.

\section{METHODS}

\section{Ethical consideration}

This observational study was evaluated and approved by the Health Research Ethics Committee of Faculty of Medicine Universitas Muhammadiyah Surakarta Number: 1894/B.1/KEPK-FKUMS/II/2019.

\section{Study design}

This study is an observational with cross-sectional design.

The requirements of population and sample of this study were: (1) Active students at non-medical faculties of Universitas Muhammadiyah Surakarta in 2019; (2) ever get dysmenorrhea before or during menstrual cycle or both; and (3) willing to be a respondent by signing informed consent. The samples of this study were 394 respondents from 718 populations by purposive sampling method.

\section{Questionnaire and data collection}

Respondent filled out a questionnaire was given by researcher. The questionnaire consists of two sections. The first section comprised demographic data of respondent including age and faculty. The second section comprised dysmenorrhea management, including pharmacology and non-pharmacology treatment. 
Data analysis

Data were analyzed descriptively by calculating the percentage (\%) of each category.

\section{RESULTS AND DISCUSSION}

\section{Demographics of respondents}

Age and faculty were that two characteristics of respondent were described in this study. According to Table. 1, the age was varying between 17 and 24 years old (most widely in 19 years old). There were 7 (seven) non-medical faculties in Universitas Muhammadiyah Surakarta which are involved in this study. The most widely respondents were came from faculty of teacher training and education (almost 30\%). Socio-demographic factor (as age) did not influence the rationality of self-medication [7]

\section{Dysmenorrhea management by respondents}

Respondents of this study did pharmacological and non-pharmacological treatment to reduce dysmenorrhea symptoms, as shown in Table 2. Sleeping and taking a rest were the most widely non-pharmacological treatment which was done by almost $90 \%$ respondents. Another study also mentioned that more than half respondents only rest enough during

Table 1: Demographics of respondents at non-medical faculties of Universitas Muhammadiyah Surakarta in 2019

\begin{tabular}{lll}
\hline Aspect & Frequency & $\begin{array}{l}\text { Percentage (\%) } \\
\mathbf{n = 3 9 4}\end{array}$ \\
\hline Age & 3 & \\
17 years old & 55 & 0.77 \\
18 years old & 116 & 14.03 \\
19 years old & 103 & 29.59 \\
20 years old & 75 & 26.28 \\
21 years old & 36 & 19.13 \\
22 years old & 3 & 9.18 \\
23 years old & 1 & 0.77 \\
24 years old & & 0.26 \\
Faculty & 42 & 10.71 \\
Faculty of Engineering & 32 & 8.16 \\
Faculty of Law & 15 & 3.83 \\
Faculty of Geography & 69 & 17.60 \\
Faculty of Islamic Religion & 103 & 26.28 \\
Faculty of Economics and Business & 6.12 \\
Faculty of Communication and & 24 & \\
Information & & 27.30 \\
Faculty of Teacher Training and & 107 & \\
Education & & \\
\hline
\end{tabular}

Table 2: Dysmenorrhea management by non-medical faculties students of Universitas Muhammadiyah Surakarta in 2019

\begin{tabular}{lll}
\hline Action & Frequency & Percentage (\%) $\mathbf{n = 3 9 4}$ \\
\hline $\begin{array}{l}\text { Non-pharmacological } \\
\quad \text { Sleeping and taking a rest }\end{array}$ & 348 & 88.78 \\
$\begin{array}{l}\text { Eating nutritious foods } \\
\text { Compressing with warm }\end{array}$ & 211 & 53.83 \\
water & 166 & 42.35 \\
$\begin{array}{l}\text { Drinking traditional } \\
\text { medicine (herbal) }\end{array}$ & 134 & 34.18 \\
$\begin{array}{l}\text { Listening to music } \\
\text { Aromatherapy }\end{array}$ & 127 & 32.40 \\
$\begin{array}{l}\text { Doing exercise } \\
\text { Massage }\end{array}$ & 57 & 24.74 \\
$\begin{array}{l}\text { Pharmacological } \\
\text { Taking medication from } \\
\text { pharmacies, clinics, and }\end{array}$ & 147 & 14.54 \\
drug stores & & 19.64 \\
Taking medication from & 14 & 37.24 \\
the stall & & \\
\hline
\end{tabular}

the period [8]. A study showed a significant relationship between a lowfat vegetarian diet and symptom reduction by affecting prostaglandin metabolism [9]. More than 50\% respondents in this study choose eating nutritious foods to manage dysmenorrhea. However, the kind of foods that they were taken were not investigated yet in this study. The use of heat patch $\left(39^{\circ} \mathrm{C}\right)$ for $12 \mathrm{~h}$ a day is as effective as ibuprofen $400 \mathrm{mg} 3$ times a

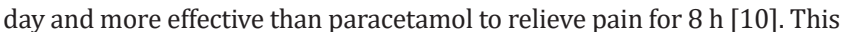
activity was done by $42.35 \%$ respondents in this study too.

The use of herbal therapy is very popular because it can be managed alone and available at health stores, chemists, and supermarkets. This despite the availability of useful can create problems with dosage control, quality, and drug interactions. Kiranti ${ }^{\circledR}$ was the most widely herbal medicine that was used in this study. Kiranti's ingredients are extract of Curcuma longa, Tamarindus indica, Kaempferia galanga, Pandanus amaryllifolius, Zingiber officinale, and Cinnamomum verum. Clinical trial of this product indicated that it reduce menstrual pain, vaginal discharge, and safe for consumption. Physical exercise also can reduce dysmenorrhea by increasing blood flow to the pelvic and stimulating the release of beta endorphins which act as non-specific analgesics. Compared to no treatment, exercise showed large effect in reducing menstrual pain [11]. Massage is effective in reducing dysmenorrhea and the effect of aromatherapy massage on pain is higher than placebo massage [6]. The choice of dysmenorrhea management was influenced by severity and duration of pain, inability to work and sleep, also loss of appetite [8].

According to Table 2, almost 40\% respondents taking medication from pharmacies, clinics and drug stores. However, more than $70 \%$ of those respondents did not know the category or brand name of medicines they took, as shown in Table 3. In this case, the rationality of self-medication was depending on information from pharmacists. A miss usage of medicine can occur if respondents do not used properly based on pharmacist's information. When pharmacy staff handling self-medication request, there were deficits in the type of information gathered [4].

Combination paracetamol and hyoscyamine extract were widely used by respondents in this study. Mefenamic acid was used by almost $5 \%$ of 160 respondents in this study. This medicine is NSAIDs. The effectiveness and tolerability of each patient should be considered before using these medicines [12]. The objective of dysmenorrhea treatments was relieve pain or symptoms by affecting the physiological mechanisms behind menstrual pain (such as prostaglandin production). Paracetamol and NSAIDs (mefenamic acid and ibuprofen) work by reducing the activity of the cyclooxgenase pathway, thereby inhibiting prostaglandin production [1].

Table 3: The list of medicine that was used on dysmenorrhea management by non-medical faculties students of Universitas Muhammadiyah Surakarta in 2019

\begin{tabular}{llll}
\hline Category & Medicine & Frequency & $\begin{array}{l}\text { Percentage (\%) } \\
\mathbf{n = 1 6 0}\end{array}$ \\
\hline OWA & Mefenamic acid & 7 & 4.37 \\
& Ibuprofen & 6 & 3.75 \\
& Methampiron & 4 & 2.50 \\
& Methampiron- & 1 & 0.62 \\
& Beladona & & \\
& Extract- & & \\
OTC & Papaverin & & \\
& Hydrochloride & & \\
& Paracetamol- & 24 & 15.00 \\
& Hyosiami & & \\
POM & Extract & & 1.88 \\
Unidentified & Paracetamol & 3 & 0.62 \\
\hline & Amoxycillin & 1 & 0.62 \\
& Ketoprofen & 1 & 70.62 \\
\hline
\end{tabular}

OWA: Mandatory drug pharmacy, OTC: Over the counter, POM: Prescription only medicine 
Only $1.24 \%$ of 160 respondents get inappropriate medicine that is amoxicillin and ketoprofen. Both are $\mathrm{G}$ drugs that can be given to patients by prescription only. Besides that, amoxicillin is an antibiotic. This is not the drug of choice to reduce the symptoms of dysmenorrhea. Inappropriate use of antibiotic leads higher morbidity and mortality that caused by resistance. A study mentioned that age, family income, and knowledge are influence self-medication practices with antibiotic. Education programs to improve public awareness are needed [13].

\section{CONCLUSION}

The finding of this observational study with cross-sectional design among 394 respondents at non-medical faculties of Universitas Muhammadiyah Surakarta was students at non-medical faculties of Universitas Muhammadiyah Surakarta did both of pharmacological and non-pharmacological treatment to manage dysmenorrhea. All of respondents managed dysmenorrhea by non-pharmacological treatment (88.78\%, 53.83\%, and $42.35 \%$ were sleeping and taking a rest, eating nutritrious food, and compressing with warm water). Whereas 160 (40.82\%) respondents managed dysmenorrhea by taking medicines (70.62\%, 16.88\%, $11.25 \%$ and $1.25 \%$ were unidentified, OTC, mandatory drug pharmacy [Obat Wajib Apotek], and prescription only medicine).

Dysmenorrhea management among non-medical faculties students of Universitas Muhammadiyah frequently appropriate. The role of pharmacists in providing information about medicine used by community was very important because many respondents do not know the names or brands.

The future research expected to be able to identify the rationality of medicine that was taken by respondent to manage dysmenorrhea based on the appropriate patient dan dose.

\section{ACKNOWLEDGMENTS}

The author would like to thank the Dean of non-medical faculties in the Universitas Muhammadiyah Surakarta and all the respondents of this study.

\section{CONFLICTS OF INTEREST}

All authors have none to declare.

\section{REFERENCES}

1. Proctor M, Farquhar C. Diagnosis and management of dysmenorrhoea. BMJ 2006;332:1134-8.

2. Dharmapuri S. Dysmenorrhea in adolescents. Pediatr Med 2019;2:1-9.

3. Kennedy E, Clyde J. Responding to minor ailments. Scotland: NHS; 2008.

4. Brata C, Marjadi B, Schneider CR, Murray K, Clifford RM. Information-gathering for self-medication via Eastern Indonesian community pharmacies: A cross sectional study. BMC Health Serv Res 2015; $15: 8$.

5. Handayani T, Priyatno D. Drug regulation in self medication. J Biol Med Res 2018;2:9.

6. Apay SE, Arslan S. Effects of aromatherapy massage on dysmenorrhea in Turkish students. Pain Manag Nurs 2012;13:236-40.

7. Harahap NA, Khairunnisa, Tanuwijaya J. Patient knowledge and rationality of self-medication in three pharmacies of Panyabungan City, Indonesia. J Sains Farm Klin 2017;3:186-92.

8. Adeoye TE, Arulogun OS, Dipeolu IO, Jidda KA. Experience of dysmenorrhoea and self-care strategies among female students in a tertiary institution, Ibadan, Nigeria. J Med Med Sci 2019;10:51-60.

9. Barnard ND, Scialli AR, Hurlock D, Bertron P. Diet and sex hormone binding globulin, dysmenorrhoea and premenstrual symptoms. Obstet Gynecol 2000;95:245-50.

10. Akin MD, Weingand KW, Hengehold DA, Goodale MB, Hinkle RT, Smith RP. Continous low-level topical heat in the treatment of dysmenorrhoea. Obstet Gynecol 2001;97:343-9.

11. Armour M, Smith CA, Steel KA, Macmillan F. The effectiveness of self-care and lifestyle intervention in primary dysmenorrheal: A systematic review and meta-analysis. BMC Complement Altern Med 2019;19:22.

12. Osayande A, Mehulic S. Diagnosis and initial management of dysmenorrhea. Am Fam Phys 2014;89:1-11.

13. Kurniawan, Posangi J, Rampengan N. Association between public knowledge regarding antibiotics and self-medication with antibiotics in Teling Atas community health center, East Indonesia. Med J Indones 2017;26:62-9. 